\title{
Pengaruh Perbandingan Mocaf Dengan Tepung Daun Papasan (Coccinia Grandis) Terhadap Karakteristik Kue Stik
}

\section{Effect Of Comparison Of Mocaf And Papasan Leaf Flour (Coccinia Grandis) On Characteristics Of Stick Cake.}

\author{
Ni Kadek Ayu Puspitayanti ${ }^{1}$, N.L.A. Yusasrini ${ }^{1 *}$, I Gusti Ayu Ekawati ${ }^{1}$ \\ Program Studi Teknologi Pangan, Fakultas Teknologi Pertanian, \\ Universitas Udayana, Kampus Bukit Jimbaran, Badung-Bali \\ Penulis korespondensi: N.L.A.Yusasrini, Email: ariyusasrini@unud.ac.id
}

\begin{abstract}
This study aims to determine the effect of mocaf comparison with papasan leaf flour on the characteristics of stick cake and to find out the proper mocaf comparison with papasan leaf flour so as to produce the best stick cake characteristics. The Completely Randomized Design (CRD) was used a with the treatment of mocaf comparison and papasan leaf flour which consists of 5 levels, namely: 100\% mocaf: $0 \%$ papasan leaf flour, 95\% mocaf: 5\% papasan leaf flour, 90\% mocaf: $10 \%$ papasan leaf flour, $85 \%$ mocaf: $15 \%$ papasan leaf flour, and $80 \%$ mocaf: $20 \%$ papasan leaf flour. The research data were analyzed of variance (ANOVA) and if the treatment had a significant effect it was continued with Duncan's Multiple Range Test (DMRT). The results showed that the comparison of mocaf and papasan leaf flour to the resulting sticks had a very significant effect on water content, ash content, antioxidant activity, total chlorophyll, calcium levels, breaking strength of cake sticks and sensory properties including texture, taste, color, aroma, and overall acceptance. The best characteristics produced in the treatment of $95 \%$ mocaf: $5 \%$ papasan leaf flour that produces a water content of $1.70 \%$, ash content of $4.24 \%$, antioxidant activity of $11.39 \%$, total chlorophyll content of $89.52 \mathrm{mg} / \mathrm{L}$, calcium content of $238.73 \mathrm{mg} / \mathrm{g}$, fracture power of $13.07 \mathrm{~N}$, and sensory characteristics include greenish brown color and like, aroma like, taste rather typical of papasan leaves and very like, crispy and like texture, overall acceptance of likes .
\end{abstract}

Keywords : papasan leafflour, mocaf, cake sticks.

\section{PENDAHULUAN}

Kue stik merupakan jenis kue kering dengan bahan dasar terigu, tepung tapioka atau tepung sagu, lemak, telur serta air, yang berbentuk pipih panjang, rasanya gurih, bertekstur renyah dan proses akhirnya dengan cara digoreng (Pratiwi, 2013). Kue stik yang beredar di pasaran memiliki banyak varian rasa sehingga disukai mulai dari kalangan anak-anak, remaja, dan dewasa. Kue stik pada umumnya memiliki kandungan gizi per
100 gramnya yaitu karbohidrat sebesar 64,6 $\mathrm{g}$, protein $8,8 \mathrm{~g}$, lemak $21,6 \mathrm{~g}$, dan rendah kandungan seratnya (Anon, 2010). Seiring dengan perkembangan zaman pengolahan kue stik sudah berkembang dengan menggunakan inovasi baru yaitu mengganti terigu dengan bahan pangan lokal salah satunya yaitu tepung mocaf. Hal tersebut dikarenakan mocaf memberikan keuntungan terutama untuk mereka penderita autis atau mereka yang tidak mengkonsumsi gluten. 
Mocaf (Modified cassava flour) adalah salah satu produk pati termodifikasi yang telah banyak dimanfaatkan sebagai produk pangan (Nia, 2018). Mocaf bisa mengganti terigu hal tersebut dikarenakan mocaf memiliki kadar pati yang hampir sama dengan kadar pati pada terigu (Kristiastuti,2016). Mocaf memiliki kandungan gizi seperti pati sebesar 85,60\%, protein $1,93 \%$, lemak $2,72 \%$, abu $0,30 \%$,air 9,25\%,serat 0,21\% (Hidayat, et al., 2009). Mocaf juga mengandung fitoestrogen yaitu suatu hormon yang berfungsi untuk mencegah menopause dini yang biasa terjadi pada kaum wanita (Wara, 2012). Mocaf mengandung komponen bioaktif yang sangat rendah, sehingga untuk meningkatkan senyawa bioaktif dapat ditambahkan bahan pangan lain seperti sayuran.

Daun papasan merupakan salah satu sayuran lokal yang dapat digunakan sebagai sumber komponen bioaktif dalam pembuatan kue stik, karena daun papasan mengandung senyawa bioaktif berupa fenol $2,1 \mathrm{mg} / \mathrm{g}$, flavonoid sebesar $8,2 \mathrm{mg} / \mathrm{g}$ yang dapat berfungsi sebagai antioksidan,dan terdapat juga kandungan klorofil (Mala,et al., 2014). Daun papasan juga mengandung air sebesar $91 \mathrm{~g}$, karbohidrat sebesar 3,9 g, protein sebesar 3,6 g, serat 2,7 g, Fe 1,4 mg,vitamin $\mathrm{C}$ sebesar $13 \mathrm{mg}$, dan kalsium sebesar $57 \mathrm{mg}$ (Simopoulus dan Gopalan, 2003).
Di Bali, daun papasan biasanya diolah menjadi lauk pauk dan jamu tradisional. Dengan kandungan gizi yang cukup baik, maka daun papasan memiliki potensi untuk diolah menjadi produk olahan seperti kue stik. Untuk mempermudah proses pengolahan daun papasan, maka dapat dimodifikasi menjadi produk pangan yaitu dalam bentuk tepung, dikarenakan tepung memiliki kadar air yang rendah sehingga daya simpan menjadi lebih lama. Winarno (2008) melaporkan bahwa suatu bahan pangan yang tinggi kadar airnya akan semakin cepat busuk dari pada bahan pangan dengan kadar air yang rendah. Pembuatan kue stik berbahan dasar mocaf dan tepung daun papasan memerlukan perbandingan yang tepat, karena apabila penggunaan tepung daun papasan yang terlalu tinggi akan menghasilkan karakteristik yang mudah hancur dan apabila penggunaan tepung daun papasan yang terlalu rendah akan menghasilkan karakteristik yang rendah kandungan kalsium dan komponen bioaktif. Berdasarkan uraian diatas maka diperlukan penelitian tentang perbandingan mocaf dengan tepung daun papasan dengan harapan dihasilkan kue stik mocaf dengan karakteristik terbaik. Oleh karena itu penelitian ini bertujuan untuk mengetahui pengaruh perbandingan mocaf dengan tepung daun papasan terhadap karakteristik kue stik dan untuk mengetahui perbandingan mocaf dengan tepung daun 
papasan yang tepat sehingga menghasilkan kue stik dengan karakteristik terbaik.

\section{METODE PENELITIAN}

\section{Tempat dan Waktu Penelitian}

Penelitian ini akan dilaksanakan di Laboratorium Pengolahan Pangan dan Laboratorium Analisis Pangan Program Studi Ilmu dan Teknologi Pangan, Fakultas Teknologi Pertanian, Universitas Udayana. Penelitian ini dilaksanakan dari awal bulan Januari sampai dengan awal april 2020.

\section{Bahan dan Alat}

Bahan yang digunakan dalam penelitian ini yaitu terdiri dari bahan utama, bahan pendukung atau tambahan dan bahan kimia untuk menguji karakteristik kimia. Untuk bahan utama terdiri dari mocaf dan tepung daun papasan. Daun papasan yang dipergunakan diperoleh dari Desa Yehembang Kauh, Kabupaten Jembrana yaitu dengan ciri-ciri daun yang muda berbentuk bulat, berlekuk, licin, tidak berambut, panjang daun 8-9,2 $\mathrm{cm}$ dan lebar daunnya $6,6-7,4 \mathrm{~cm}$ dan diambil 4 daun dari pucuk. Bahan pendukung terdiri dari bawang putih, garam, telur dan margarin. Bahan kimia yang digunakan terdiri dari pelarut heksan, aquades, $\mathrm{NaOH}$, alkohol $95 \%, \mathrm{H}_{2} \mathrm{SO}_{4}$, dan $\mathrm{K}_{2} \mathrm{SO}_{4}$.

Alat yang digunakan dalam penelitian ini yaitu ayakan 80 mesh, blender, nampan besar, baskom besar, timbangan analitik, desikator, pasta maker, wajan, spatula, kompor, thermometer, penyaringan, penggaris, pisau, cawan porcelain, oven, pipet tetes, meja, cawan, cawan porselin, pinset, eksikator, muffle, pipet tetes, erlenmeyer, kertas saring, batang pengaduk, corong, pipet ukur, termometer, gelas ukur, gelas beker.

\section{Rancangan Penelitian dan Analisa Data}

Rancangan yang digunakan dalam penelitian ini yaitu Rancangan Acak Lengkap (RAL) dengan perlakuan perbandingan mocaf dan tepung daun papasan sebanyak 5 perlakuan yaitu : P0 (100\% mocaf : $0 \%$ tepung daun papasan), P1 (95 \% mocaf : $5 \%$ tepung daun papasan), P2 (90\% mocaf : $10 \%$ tepung daun papasan), P3 (85\% mocaf : $15 \%$ tepung daun papasan), P4 (80 \% mocaf : 20 $\%$ tepung daun papasan). Setiap perlakuan diulang sebanyak 3 kali sehingga diperoleh 15 unit percobaan. Untuk analisis datanya menggunakan sidik ragam Analysis of Variance (ANOVA) dan apabila perlakuan berpengaruh terhadap variable yang diamati maka akan dilanjutkan ke uji Duncan DMRT (Gomez dan Gomez, 1995).

\section{Pelaksanaan Penelitian}

\section{Pembuatan Tepung Daun Papasan}

Pembuatan tepung daun papasan ini menggunakan metode yang dilaporkan Zakaria et al. (2012) yang dimodifikasi. Daun papasan muda dipetik dan dicuci dengan air bersih lalu dipisahkan dari tangkai daunnya. Daun papasan ditebar pada rak oven dan diatur ketebalan yaitu 1 $\mathrm{cm}$ selanjutnya dikeringkan menggunakan 
suhu $45^{\circ} \mathrm{C}$ selama 24 jam. Daun papasan kering diblender sampai halus dan diayak menggunakan ayakan 60 mesh.

\section{Pembuatan Kue stik}

Bahan yang digunakan untuk pembuatan kue stik yaitu mocaf, tepung daun papasan, bawang putih, garam, margarin, dan telur di timbang terlebih dahulu sesuai dengan formula pada Tabel 1. Pada pembuatan kue stik diawali dengan mocaf, tepung daun papasan, baking soda dan garam dicampur sesuai perlakuan sampai tercampur rata. Dimasukkan bawah putih, margarin, telur dan air, kemudian diuleni sampai kalis. Adonan digiling menggunakan pasta maker dengan panjang $12 \mathrm{~cm}$, lebar $10 \mathrm{~cm}$ dan tebal $0,1 \mathrm{~cm}$. Lembaran adonan dibentuk menggunakan pasta maker dengan panjang $10 \mathrm{~cm}$, lebar $0,5 \mathrm{~cm}$ dan tebal $0,1 \mathrm{~cm}$. Kue stik digoreng dengan suhu $120^{\circ} \mathrm{C}$ selama 3 menit (Kristiastuti, 2016).

Tabel 1. Formula kue stik dengan perbandingan mocaf dan tepung daun papasan

\begin{tabular}{lccccc}
\hline \multirow{2}{*}{$\begin{array}{c}\text { Komposisi Bahan } \\
\text { Mocaf }\end{array}$} & P0 & P1 & P2 & P3 & P4 \\
\cline { 2 - 6 } & 100 & 95 & 90 & 85 & 80 \\
Tepung daun papasan & 0 & 5 & 10 & 15 & 20 \\
Bawang putih & 4 & 4 & 4 & 4 & 4 \\
Garam & 3 & 3 & 3 & 3 & 3 \\
Margarin & 9 & 9 & 9 & 9 & 9 \\
Telur & 36 & 36 & 36 & 36 & 36 \\
Air & 50 & 50 & 50 & 50 & 50 \\
Baking Soda & 4 & 4 & 4 & 4 & 4 \\
\hline
\end{tabular}

Keterangan: Persentase berdasarkan jumlah mocaf dan tepung daun papasan (100 g)

\section{HASIL DAN PEMBAHASAN}

Nilai kadar air, kadar abu, aktivitas antioksidan, kadar klorofil dan kadar kalsium dari mocaf dan tepung daun papasan dapat dilihat pada Tabel 2. Mocaf memiliki komponen gizi seperti air sebesar $6,46 \%$. Bahan baku mocaf adalah singkong yang memiliki kadar air cukup tinggi sebesar 62,50\% (Anon, 1981). Kadar air mocaf yang rendah dikarenakan pada proses pembuatan mocaf, air dalam bahan mengalami penguapan yang disebabkan oleh panas pada proses pengeringan di dalam oven, sehingga kadar air pada mocaf mengalami penurunan. Selain itu mocaf juga memiliki kadar abu sebesar $0,84 \%$ hal tersebut dikarenakan bahan baku mocaf memiliki komponen gizi mineral seperti fosfor sebesar $40 \mathrm{mg}$ dan zat besi sebesar 0,70 mg. Mocaf memiliki aktivitas antioksidan sebesar $0,64 \%$ hal tersebut dikarenakan bahan baku mocaf memiliki kandungan vitamin $\mathrm{C}$ sebesar $30 \mathrm{mg} / 100 \mathrm{~g}$ 
yang dapat berfungsi sebagai antioksidan (Anon,1981).

Tepung daun papasan memiliki kadar air sebesar 8,45\%. Menurut Simopoulus dan Gopalan (2003) daun papasan segar memiliki kadar air sebesar 91\%. Rendahnya kadar air tepung daun papasan dikarenakan pada proses pembuatan tepung daun papasan, air dalam bahan mengalami penguapan yang disebabkan oleh panas pada proses pengeringan di dalam oven, sehingga kadar air pada tepung daun papasan mengalami penurunan. Selain itu tepung daun papasan juga memiliki kadar abu sebesar 19,46\% hal tersebut dikarenakan pada daun papasan mengandung mineral sebesar $22,14 \%$ (Parab, et al., 2016). Sudarmadji, et al., (1997) melaporkan bahwa kadar abu berhubungan erat dengan kandungan mineral yang terdapat dalam suatu bahan pangan. Tepung daun papasan juga memiliki aktivitas antioksidan sebesar 40,04\%, hal tersebut dikarenakan daun papasan memiliki senyawa bioaktif diantaranya yaitu senyawa fenol dan flavonoid. Selain itu tepung daun papasan juga memiliki klorofil sebesar 2.279,83 mg/L. Daun papasan memiliki komponen gizi seperti $\mathrm{Fe}$ sebesar 1,4 mg/100 gr (Simopoulus dan Gopalan 2003), dimana Fe ini berfungsi sebagai pembentuk dan katalis dalam sintesis klorofil. Selain itu tepung daun papasan juga memiliki kalsium sebesar $3616,98 \mathrm{mg} / \mathrm{mL}$.

Hasil analisis kimia kadar air, kadar abu dan aktivitas antioksidan kue stik dengan perbandingan mocaf dan tepung daun papasan dapat dilihat pada Tabel 2, dan hasil analisis kimia kadar total klorofil, kadar kalsium dan daya patah kue stik dengan perbandingan mocaf dan tepung daun papasan dapat dilihat pada Tabel 3 dan Tabel 4.

Tabel 2. Nilai rata-rata kadar air, kadar abu, aktivitas antioksidan, kadar klorofil dan kadar kalsium kue stik

\begin{tabular}{lcc}
\hline \multicolumn{1}{c}{ Komponen } & Mocaf & Tepung Daun Papasan \\
\hline Kadar Air (\%) & $6,46 \pm 0,24$ & $8,45 \pm 0,34$ \\
Kadar Abu (\%) & $0,84 \pm 0,02$ & $19,64 \pm 0,40$ \\
Antioksidan (\%) & $0,64 \pm 0,28$ & $40,04 \pm 0,69$ \\
Klorofil (mg/l) & - & $2.279,83 \pm 18,99$ \\
Kalsium (mg/kg) & - & $3616,93 \pm 0,03$ \\
\hline
\end{tabular}

Ket : Tanda (-) artinya tidak terdapat komponen gizi tersebut dalam bahan

\section{Kadar Air}

Hasil sidik ragam menunjukkan bahwa perbandingan mocaf dan tepung daun papasan berpengaruh sangat nyata
$(\mathrm{P}<0,01)$ terhadap kadar air kue stik. Pada Tabel 3 menunjukan bahwa rata-rata kadar air kue stik berkisar antara 1,07\% - 3,70\%. Nilai rata-rata kadar air tertinggi sebesar 
$3,70 \%$ terdapat pada perlakuan P4 ( $80 \%$ mocaf : 20\% daun papasan). Nilai rata-rata kadar air terendah sebesar $1,07 \%$ terdapat pada perlakuan P0 (100\% mocaf : 0\% daun papasan). Semakin banyak penggunaan tepung daun papasan maka kadar air yang dihasilkan akan semakin meningkat, hal ini disebabkan karena tepung daun papasan memiliki kadar air yang lebih tinggi sebesar $8,45 \%$ dibandingkan dengan mocaf memiliki kadar air sebesar 6,46\%. Menurut SNI 2886 tahun 2015 tentang makanan ekstrudat kadar air maksimal adalah 4\%, maka semua perlakuan pada pembuatan kue stik sudah memenuhi kriteria SNI yang ditentukan.

Tabel 3. Hasil analisis kimia kadar air, kadar abu, dan aktivitas antioksidan kue stik dengan perbandingan mocaf dan tepung daun papasan.

\begin{tabular}{cccc}
\hline Perlakuan & Kadar Air (\%) & Kadar Abu (\%) & Aktivitas Antioksidan (\%) \\
\hline P0 & $1,07 \pm 0,05 \mathrm{e}$ & $3.63 \pm 0,03 \mathrm{e}$ & $5,07 \pm 0,10 \mathrm{e}$ \\
P1 & $1,70 \pm 0,06 \mathrm{~d}$ & $4,42 \pm 0,01 \mathrm{~d}$ & $11,39 \pm 0,41 \mathrm{~d}$ \\
P2 & $2,57 \pm 0,01 \mathrm{c}$ & $4,56 \pm 0,04 \mathrm{c}$ & $13,15 \pm 0,33 \mathrm{c}$ \\
P3 & $3,03 \pm 0,01 \mathrm{~b}$ & $4,74 \pm 0,04 \mathrm{~b}$ & $25,22 \pm 0,14 \mathrm{~b}$ \\
P4 & $3,70 \pm 0,06 \mathrm{a}$ & $5,15 \pm 0,05 \mathrm{a}$ & $31,92 \pm 0,72 \mathrm{a}$ \\
\hline
\end{tabular}

Keterangan: Nilai rata-rata yang diikuti oleh huruf yang berbeda pada kolom yang sama diatas menunjukan perbedaan yang sangat nyata $(\mathrm{P}<0,01)$

Tabel 4. Hasil analisis kimia kadar total klorofil, kadar kalsium dan daya patah kue stik dengan perbandingan mocaf dan tepung daun papasan.

\begin{tabular}{cccc}
\hline Perlakuan & $\begin{array}{c}\text { Kadar total klorofil } \\
(\mathrm{mg} / \mathrm{L})\end{array}$ & $\begin{array}{c}\text { Kadar Kalsium } \\
(\mathrm{mg} / \mathrm{g})\end{array}$ & $\begin{array}{c}\text { Daya Patah } \\
(\mathrm{N})\end{array}$ \\
\hline P0 & $26,81 \pm 0,37 \mathrm{e}$ & $24,53 \pm 0,06 \mathrm{e}$ & $21,09 \pm 0,12 \mathrm{a}$ \\
P1 & $89,52 \pm 0,03 \mathrm{~d}$ & $238,73 \pm 0,05 \mathrm{~d}$ & $13,07 \pm 0,37 \mathrm{~b}$ \\
P2 & $111,38 \pm 0,79 \mathrm{c}$ & $956,23 \pm 0,05 \mathrm{c}$ & $10,81 \pm 0,40 \mathrm{c}$ \\
P3 & $146,15 \pm 2,93 \mathrm{~b}$ & $1054,13 \pm 0,04 \mathrm{~b}$ & $5,76 \pm 0,23 \mathrm{~d}$ \\
P4 & $215,03 \pm 3,80 \mathrm{a}$ & $1110,61 \pm 0,08 \mathrm{a}$ & $4,22 \pm 0,21 \mathrm{e}$ \\
\hline
\end{tabular}

Keterangan : Nilai rata-rata yang diikuti oleh huruf yang berbeda pada kolom yang sama diatas menunjukan perbedaan yang sangat nyata $(\mathrm{P}<0,01)$

\section{Kadar Abu}

Hasil sidik ragam menunjukkan bahwa perbandingan mocaf dan tepung daun papasan berpengaruh sangat nyata $(\mathrm{P}<0,01)$ terhadap kadar abu kue stik. Pada Tabel 3 menunjukan bahwa rata-rata kadar abu kue stik berkisar antara 3,63\% - 5,15\%. Nilai rata-rata kadar abu tertinggi sebesar $5,15 \%$ terdapat pada perlakuan P4 ( $80 \%$ mocaf : $20 \%$ tepung daun papasan). Nilai rata-rata kadar abu terendah sebesar 3,63\% terdapat pada perlakuan P0 (100\% mocaf : $0 \%$ tepung daun papasan). Hal ini menunjukkan bahwa semakin banyak penggunaan tepung daun papasan pada pembuatan kue stik maka kadar abu yang dihasilkan semakin meningkat hal tersebut disebabkan karena hasil analisis bahan baku 
tepung daun papasan lebih tinggi dari pada mocaf. Menurut Parab, et al., (2016) daun papasan mempunyai komponen gizi mineral sebesar 22,14\%. Sesuai dengan pernyataan Sudarmadji, et al., (1997), kadar abu berhubungan erat dengan kandungan mineral yang terdapat dalam suatu bahan pangan. Menurut Winarno (2008), kadar abu adalah unsur mineral atau zat anorganik yang tidak terbakar pada saat pembakaran.

\section{Aktivitas Antioksidan}

Hasil sidik ragam menunjukkan bahwa perbandingan mocaf dan tepung daun papasan berpengaruh sangat nyata $(\mathrm{P}<0,01)$ terhadap aktivitas antioksidan kue stik. Pada Tabel 3 menunjukkan bahwa rata-rata aktivitas antioksidan kue stik berkisar antara 5,07\% - 31,92\%. Nilai ratarata aktivitas antioksidan tertinggi sebesar $31,92 \%$ terdapat pada perlakuan P4 (80\% mocaf : $20 \%$ tepung daun papasan). Nilai rata-rata aktivitas antioksidan terendah sebesar 5,07\% terdapat pada perlakuan P0 (100\% mocaf : $0 \%$ tepung daun papasan).

Semakin banyak penggunaan tepung daun papasan dari mocaf maka akan meningkatkan aktivitas antioksidan pada kue stik. Hal ini karena tepung daun papasan merupakan salah satu bahan baku yang memiliki antioksidan cukup tinggi. Dari hasil analisis bahan baku tepung daun papasan mengandung antioksidan sebesar $40,04 \%$, sedangkan mocaf mengandung antioksidan yang lebih rendah sebesar $0,64 \%$.
Antioksidan merupakan suatu substansi yang pada konsentrasi kecil secara signifikan mampu menghambat atau mencegah oksidasi pada substrat yang disebabkan oleh radikal bebas (Isnindar, et.,al, 2011). Tepung daun papasan merupakan salah satu bahan baku yang memiliki antioksidan yang cukup tinggi. Senyawa yang berpotensi sebagai antioksidan pada daun papasan salah satunya yaitu senyawa fenol dan flavonoid, dimana fenol pada daun papasan sebesar $2,1 \mathrm{mg} / \mathrm{g}$ dan flavonoid sebesar $8,2 \mathrm{mg} / \mathrm{g}$ (Mala, et al.,2014).

\section{Kadar Total Klorofil}

Hasil sidik ragam yang telah dilakukan menunjukkan bahwa perbandingan mocaf dan tepung daun papasan berpengaruh sangat nyata $(\mathrm{P}<0,01)$ terhadap kadar total klorofil kue stik. Tabel 4 menunjukkan bahwa rata-rata kadar total klorofil pada kue stik berkisar antara 26,81 $\mathrm{mg} / \mathrm{L}-215,03 \mathrm{mg} / \mathrm{L}$. Nilai rata-rata kadar total klorofil tertinggi terdapat pada perlakuan P4 (80\% mocaf : 20\% tepung daun papasan) yaitu sebesar 215,03 mg/L. Nilai rata-rata total klorofil terendah sebesar $26,81 \mathrm{mg} / \mathrm{L}$ yaitu terdapat pada perlakuan P0 (100\% mocaf : 20\% tepung daun papasan). Hal ini disebabkan karena daun papasan merupakan salah satu bahan baku yang memiliki klorofil cukup tinggi. Dari hasil analisis bahan baku, tepung daun papasan mengandung klorofil sebesar 
2.279,83 $\mathrm{mg} / \mathrm{L}$, sedangkan mocaf tidak mengandung klorofil.

\section{Kalsium}

Kalsium merupakan zat gizi mikro yang dibutuhkan oleh tubuh dan mineral yang paling banyak terdapat dalam tubuh yaitu $1,5-2 \%$ dari berat badan orang dewasa. Berdasarkan hasil sidik ragam menunjukkan bahwa perbandingan mocaf dan tepung daun papasan berpengaruh sangat nyata $(\mathrm{P}<0,01)$ terhadap kandungan kalsium pada kue stik. Tabel 4 menunjukkan bahwa nilai rata-rata kalsium kue stik berkisar antara 24,53 mg/g - $1110,61 \mathrm{mg} / \mathrm{mL}$. Nilai rata-rata kalsium tertinggi terdapat pada perlakuan P4 (80\% mocaf : $20 \%$ tepung daun papasan) yaitu sebesar 1110,61 mg/g . Nilai rata-rata kalsium terendah sebesar 24,53 $\mathrm{mg} / \mathrm{g}$ terdapat pada perlakuan P0 (100\% mocaf : $0 \%$ tepung daun papasan). Hal ini disebabkan karena daun papasan merupakan salah satu bahan baku yang memiliki kalsium cukup tinggi. Dari hasil analisis bahan baku, tepung daun papasan mengandung kalsium sebesar 3616,93 $\mathrm{mg} / \mathrm{mL}$, sedangkan mocaf tidak mengandung kalsium.

\section{Daya Patah}

Hasil sidik ragam menunjukkan bahwa perbandingan mocaf dan tepung daun papasan berpengaruh sangat nyata $(\mathrm{P}<0,01)$ terhadap daya patah kue stik. Pada Tabel 4 menunjukkan bahwa rata-rata daya patah kue stik berkisar antara 4,22N $21,09 N$. Nilai rata-rata daya patah tertinggi sebesar 21,09 $\mathrm{N}$ terdapat pada perlakuan P0 (100\% mocaf : 0\% tepung daun papasan). Nilai rata-rata daya patah terendah sebesar $4,22 \mathrm{~N}$ terdapat pada perlakuan P4 (80\% mocaf : 20\% tepung daun papasan). Hal tersebut dikarenakan semakin tinggi penggunaan tepung daun papasan dari pada mocaf maka daya patah kue stik semakin rendah yang disebabkan karena tepung daun papasan memiliki kadar air yaitu sebesar 8,45\%. Daya patah merupakan salah satu faktor yang penting dalam menentukan mutu sebuah kue stik. Daya patah ini disebut juga dengan kerenyahan, daya patah dapat dipengaruhi oleh kadar air bahan baku yang digunakan dalam pembuatan kue stik.

\section{Sifat Sensoris}

Uji sensoris pada kue stik dilakukan dengan uji skoring terhadap warna, rasa dan tekstur, dan uji hedonik terhadap warna, aroma, rasa, tesktur, dan penerimaan keseluruhan kue stik. Nilai rata-rata uji skoring terhadap warna, rasa dan tesktur dapat dilihat pada Tabel 5 dan nilai rata-rata uji hedonik terhadap warna, aroma, rasa, tekstur dan penerimaan keseluruhan dapat dilihat pada Tabel 6 .

\section{Warna}

Hasil sidik ragam menunjukkan bahwa perbandingan mocaf dan tepung daun papasan terhadap uji skoring dan uji 
hedonik warna kue stik sangat berpengaruh nyata $(\mathrm{P}<0,01)$. Tabel 4 menunjukkan bahwa nilai uji skoring warna tertinggi terdapat pada perlakuan P0 (100\% mocaf : $0 \%$ tepung daun papasan) yaitu dengan kriteria warna coklat keemasan. Nilai terendah terdapat pada perlakuan $\mathrm{P} 4(80 \%$ mocaf : $20 \%$ tepung daun papasan) yaitu dengan kriteria warna hijau tua. Semakin tinggi penggunaan tepung daun papasan maka warna kue stik akan semakin hijau. Hal ini disebabkan karena tepung daun papasan mengandung senyawa klorofil yang berwarna hijau sehingga menyebabkan perubahan warna hijau pada kue stik.

Pada Tabel 5 menunjukkan bahwa nilai uji hedonik warna kue stik tertinggi terdapat pada perlakuan P1 (95\% mocaf : $5 \%$ tepung daun papasan) yaitu dengan kriteria sangat suka. Nilai terendah terdapat pada perlakuan P4 (80\% mocaf : 20\% tepung daun papasan) yaitu dengan kriteria sangat tidak suka. Tingkat kesukaan panelis terhadap warna kue stik dapat dipengaruhi oleh warna alami pada bahan baku baik yang berasal dari mocaf maupun dari daun papasan itu sendiri. Sehingga warna kue stik yang lebih disukai adalah warna coklat kehijauan yang merupakan gabungan dari kedua bahan tersebut.

\section{Aroma}

Hasil sidik ragam menunjukkan bahwa dengan perbandingan mocaf dan tepung daun papasan terhadap uji hedonik aroma pada kue stik sangat berpengaruh nyata $(\mathrm{P}<0,01)$. Tabel 5 menunjukkan bahwa nilai uji hedonik aroma tertinggi terdapat pada perlakuan P1 (95\% mocaf : $5 \%$ tepung daun papasan) yaitu dengan kriteria sangat suka. Nilai terendah terdapat pada perlakuan P4 (80\% mocaf : $20 \%$ tepung daun papasan) yaitu dengan kriteria sangat tidak suka. Tingkat kesukaan panelis terhadap aroma kue stik dapat dipengaruhi oleh aroma alami pada bahan baku baik yang berasal dari mocaf maupun dari daun papasan itu sendiri.

Tabel 5. Nilai uji skoring warna, rasa dan tekstur kue stik mocaf dan tepung daun papasan

\begin{tabular}{cccc}
\hline Perlakuan & \multicolumn{3}{c}{ Nilai rata-rata uji skoring } \\
\cline { 2 - 4 } & Warna & Rasa & Tekstur \\
\hline P0 & $5,00 \pm 0,00 \mathrm{a}$ & $4,24 \pm 0,22 \mathrm{a}$ & $4,60 \pm 0,10 \mathrm{a}$ \\
P1 & $3,60 \pm 0,08 \mathrm{~b}$ & $4,32 \pm 0,20 \mathrm{a}$ & $4,24 \pm 0,10 \mathrm{a}$ \\
P2 & $2,60 \pm 0,12 \mathrm{c}$ & $2,92 \pm 0,18 \mathrm{~b}$ & $3,36 \pm 0,06 \mathrm{~b}$ \\
P3 & $1,56 \pm 0,08 \mathrm{~d}$ & $1,92 \pm 0,17 \mathrm{c}$ & $2,44 \pm 0,55 \mathrm{c}$ \\
P4 & $1,12 \pm 0,16 \mathrm{e}$ & $1,48 \pm 0,12 \mathrm{~d}$ & $1,72 \pm 0,33 \mathrm{~d}$ \\
\hline
\end{tabular}

Keterangan: Huruf yang berbeda dibelakang nilai rata-rata pada kolom yang sama menunjukkan berbeda sangat nyata $(\mathrm{P}<0,01)$.

Warna : 1. Hijau tua 2.Hijau 3. Hijau muda 4. Coklat kehijauan 5. Coklat keemasan

Rasa : 1.Sangat khas daun papasan 2. Khas daun papasan 3. Agak khas daun papasan 4. Khas mocaf 5. Sangat khas mocaf.

Tekstur : 1. Tidak renyah 2. Kurang renyah 3. Agak renyah 4. Renyah 5. Sangat Renyah. 
Tabel 6. Nilai rata-rata uji hedonic terhadap warna, aroma, rasa, tekstur dan penerimaan keseluruhan kue stik mocaf dan tepung daun papasan

\begin{tabular}{|c|c|c|c|c|c|}
\hline \multirow[t]{2}{*}{ Perlakuan } & \multicolumn{5}{|c|}{ Nilai rata-rata uji hedonic } \\
\hline & Warna & Aroma & Rasa & Tekstur & $\begin{array}{l}\text { Penerimaan } \\
\text { Keseluruhan }\end{array}$ \\
\hline P0 & $4,12 \pm 0,02 \mathrm{~b}$ & $4,08 \pm 0,06 \mathrm{a}$ & $4,20 \pm 0,08 \mathrm{~b}$ & $4,40 \pm 0,08 \mathrm{a}$ & $4,28 \pm 0,04 \mathrm{a}$ \\
\hline P1 & $4,76 \pm 0,12 \mathrm{a}$ & $4,16 \pm 0,16 \mathrm{a}$ & $4,72 \pm 0,06 \mathrm{a}$ & $4,48 \pm 0,08 \mathrm{a}$ & $4,36 \pm 0,04 \mathrm{a}$ \\
\hline $\mathrm{P} 2$ & $3,52 \pm 0,08 \mathrm{c}$ & $3,16 \pm 0,04 \mathrm{~b}$ & $3,32 \pm 0,38 \mathrm{c}$ & $3,04 \pm 0,38 \mathrm{~b}$ & $3,68 \pm 0,14 b$ \\
\hline P3 & $2,28 \pm 0,24 \mathrm{~d}$ & $2,16 \pm 0,18 \mathrm{c}$ & $2,32 \pm 0,26 \mathrm{~d}$ & $1,84 \pm 0,39 \mathrm{c}$ & $2,48 \pm 0,31 \mathrm{c}$ \\
\hline $\mathrm{P} 4$ & $1,44 \pm 0,10 \mathrm{e}$ & $1,76 \pm 0,22 \mathrm{~d}$ & $1,40 \pm 0,13 \mathrm{e}$ & $1,20 \pm 0,12 \mathrm{~d}$ & $1,76 \pm 0,44 \mathrm{~d}$ \\
\hline teranga & $\begin{array}{l}\text { Huruf yang be } \\
\text { berbeda sangat }\end{array}$ & $\begin{array}{l}\text { a dibelakang } \\
\text { ta }(P<0,01)\end{array}$ & rata-rata $\mathrm{Pa}$ & olom yang sa & menunjukkan \\
\hline Keterangan: & 1.Sangat tidak s & 2.Tidak suka & al 4.Suka 5.S & t suka & \\
\hline
\end{tabular}

Rasa

Hasil sidik ragam menunjukkan bahwa dengan perbandingan mocaf dan tepung daun papasan terhadap uji skoring dan uji hedonik rasa pada kue stik sangat berpengaruh nyata $(\mathrm{P}<0,01)$. Tabel 4 menunjukkan bahwa nilai dari uji skoring rasa tertinggi terdapat pada perlakuan P1 (95\% mocaf : 5\% tepung daun papasan) yaitu dengan kriteria rasa khas mocaf. Nilai rasa terendah terdapat pada perlakuan $\mathrm{P} 4$ (80\% mocaf : $20 \%$ tepung daun papasan) yaitu dengan kriteria rasa sangat khas daun papasan. Semakin tinggi penggunaan tepung daun papasan maka rasa kue stik akan semakin sangat khas daun papasan.

Tabel 5 menunjukkan bahwa nilai dari uji hedonik rasa tertinggi terdapat pada perlakuan P1 (95\% mocaf : $5 \%$ tepung daun papasan) yaitu dengan kriteria sangat suka. Nilai terendah terdapat pada perlakuan P4 (80\% mocaf : 20\% tepung daun papasan) yaitu dengan kriteria sangat tidak suka. Tingkat kesukaan panelis terhadap rasa kue stik dapat dipengaruhi oleh rasa alami pada bahan baku baik yang berasal dari mocaf maupun dari daun papasan itu sendiri. Sehingga rasa kue stik yang lebih disukai adalah rasa mocaf yang merupakan gabungan dari kedua bahan tersebut.

\section{Tekstur}

Hasil sidik ragam menunjukkan bahwa ( $\mathrm{P}<0,01)$. Tabel 4 menunjukkan bahwa nilai dari uji skoring tekstur tertinggi terdapat pada perlakuan P0 (100\% mocaf : $0 \%$ tepung daun papasan) yaitu dengan kriteria sangat renyah. Nilai kue stik terendah terdapat pada perlakuan P4 (80\% mocaf : $20 \%$ tepung daun papasan) yaitu dengan kriteria tidak renyah. Semakin tinggi penggunaan tepung daun papasan maka tekstur kue stik semakin tidak renyah. Hal ini disebabkan karena daun papasan memiliki kadar air yang cukup tinggi yaitu sebesar $8,45 \%$.

Tabel 5 menunjukkan bahwa nilai dari uji hedonik tekstur tertinggi terdapat pada perlakuan P1 (95\% mocaf : 5\% tepung 
daun papasan) yaitu dengan kriteria sangat suka. Nilai terendah terdapat pada perlakuan P4 (80\% mocaf : 20\% tepung daun papasan) yaitu dengan kriteria sangat tidak suka. Tingkat kesukaan panelis terhadap tekstur kue stik dapat dipengaruhi oleh tingkat kerenyahan dari kue stik itu sendiri. Sehingga tekstur kue stik yang lebih disukai adalah tesktur sangat renyah yang terdapat pada perlakuan P0 (100\% mocaf : $0 \%$ tepung daun papasan).

\section{Penerimaan Keseluruhan}

Hasil sidik ragam menunjukkan bahwa dengan perbandingan mocaf dan tepung daun papasan terhadap uji hedonik penerimaan keseluruhan kue stik sangat berpengaruh nyata $(\mathrm{P}<0,01)$. Tabel 5 menunjukkan bahwa nilai penerimaan keseluruhan tertinggi terdapat pada perlakuan P1 (95\% mocaf : 5\% tepung daun papasan) yaitu dengan kriteria suka. Nilai terendah terdapat pada perlakuan P4 $(80 \%$ mocaf : $20 \%$ tepung daun papasan) yaitu dengan kriteria sangat tidak suka. Tingkat kesukaan panelis terhadap penerimaan keseluruhan kue stik dapat dipengaruhi tingkat perbandingan tepung daun papasan dengan mocaf pada kue stik.

\section{KESIMPULAN DAN SARAN}

\section{Kesimpulan}

Perbandingan mocaf dan tepung daun papasan berpengaruh sangat nyata terhadap kadar air, kadar abu, aktivitas antioksidan, kadar total klorofil, kalsium, daya patah dan sifat sensoris yang meliputi tekstur, rasa, warna, aroma, dan penerimaan keseluruhan kue stik

Perlakuan yang menghasilkan karakteristik terbaik adalah 95\% mocaf : 5\% tepung daun papasan dengan kadar air sebesar $1,70 \%$, kadar abu sebesar 4,24\%, aktivitas antioksidan sebesar $11,39 \%$, kadar total klorofil sebesar 89,52 mg/L, kadar kalsium sebesar $238,73 \mathrm{mg} / \mathrm{g}$, daya patah sebesar 13,07 N, warna coklat kehijauan dan suka, aroma suka, rasa agak khas daun papasan dan sangat suka, tekstur renyah dan suka, penerimaan keseluruhan suka.

\section{Saran}

Pembuatan kue stik mocaf dan daun papasan disarankan menggunakan perbandingan 95\% mocaf : $5 \%$ tepung daun papasan.

\section{DAFTAR PUSTAKA}

Anonimus.2010. Daftar Komposisi Bahan Makanan. Direktorat Gizi Departemen Kesehatan Republik Indonesia.

Badan Standardisasi Nasional (BSN). 2004. SNI 06- 6989.13-2004. Air dan air limbah. BSN, Jakarta

Direktorat Jenderal Tanaman Pangan. 2005. Kebijakan Perbenihan Tanaman Pangan. Departemen Pertanian dan Fakultas Pertanian, Institut Pertanian Bogor.

Gomez, K. A. dan A. A. Gomez. 1995. Prosedur Statikue stik Untuk Penelitian Pertanian. UI Press, Jakarta.

Haris, G. 2009. Sifat Fisik Kimia dan Indeks Glikemi Produk Cookies Berbahan Baku Pati Garit 
(Maramtaarundinacea) Termodifikasi. IPB. Bogor

Hidayat B., Nurbani K., dan Surfiana. 2009. Karakterikue stik Tepung Ubi Kayu Modifikasi yang Diproses Menggunakan Metode Pra gelatinisasi Parsial. Jurnal Teknologi Industri dan Hasil Pertanian. Vol 14(2). Lampung Jurusan Teknologi Pertanian, Politeknik Negeri Lampung.

Kristiastuti, D. 2016. Pengaruh Subtitusi Tepung Mocaf (Modified Cassava Flour) Dan PerbandinganPuree Daun Ginseng (Talinum Triangulare) Terhadap Sifat Organoleptik Kue stik. Pendidikan Tata Boga, Fakultas Teknik, Universitas Negeri Surabaya. E-Journal Boga. Vol 5 (3):91-100

Mala, P. G, Arpita. dan S, Sunita. 2014. Coccinia grandis (L). Dept of Biotechnology and Bioinformatics. Patil University. Vol 7 (2).

Mosquera, O., Correa, Y. M., and Nino, J., 2009, Antioxidant Activity of Plants Extract from Colombian Flora Braz, J. Pharm, 19 (2A) 382-387.

Nollet, LML. 2004. Handbook of Food Analysis. Physical Characterzati-ion and Nutrient Analysis. Marcel Dekker. Inc. 1(2). New York.

Parab, M., Rutuja,G.,and S. Singh. 2016. Estimation of Essential and Mineral Elements in Edible Coccinia grandis L.Voigt in Maharashtra. School of Biotechnology and Bioinformatica
Maharashtra India. Journal of Pharmaceutical and Chemical Sciences. Vol 5(4)

Pratiwi,F.2013. Pemanfaatan Tepung aging Ikan Layang Untuk Pembuatan Stick Ikan. Jurusan Teknologi Jasa dan Produksi Fakultas Teknik Universitas Negeri Semarang.

Simopoulus,P,A, dan Gopalan,P. 2003. Plant in Human Health and Nutrition Policy. World Rev Nutr Diet. Basel, Karger. Vol 91 (60-66).

Soekarto, S.T. 1985. Penilaian Organoleptik Untuk Industri Pangan dan Pertanian. Bharata Karya Aksara. Jakarta.

Sudarmadji, B. Haryono dan Suhardi. 1997. Analisa Bahan Makanan dan Hasil Pertanian. Gramedia Pustaka Utama, Jakarta.

Wara, H. 2012. Daftar Kandungan Zat Gizi Bahan Makanan, Jurusan GMSK,IPB 2010.http://warahapsari.blogspot.com/2012/02/mocafalternatif-pengganti-tepung.html, akses 19 Oktober 2019

Winarno F. G. 2008. Kimia Pangan dan Gizi. Penerbit PT Gramedia PustakaUtama. Jakarta.

Zakaria, Tamrin, A. Sirajuddin, dan Harton, R.m. 2012. PerbandinganTepung Daun Kelor Pada Menu Makanan Sehari-hari dalam Upaya Penanggulangan Gizi Kurang pada Anak Balita. Media Gizi Pangan. 8 (1) : 95- 103. 